\title{
THE ANALYSIS OF THE STRENGTH OF THE SHIP'S HULL AFTER RUNNING AGROUND
}

\section{Radosław Kiciński*(D, Wojciech Jurczak**(D), Krzysztof Świątek*** (D)}

* Polish Naval Academy, Mechanical and Electrical Engineering Department, Śmidowicza 69 str., 81-127 Gdynia, r.kicinski@amw.gdynia.pl, ORCID: 0000-0003-3490-1301

** Polish Naval Academy, Mechanical and Electrical Engineering Department, Śmidowicza 69 str., 81-127 Gdynia, w.jurczak@amw.gdynia.pl,0000-0002-1608-7249

${ }^{* * *}$ Polish Naval Academy, Mechanical and Electrical Engineering Department, Śmidowicza 69 str., 81-127 Gdynia k.swiatek@amw.gdynia.pl, 0000-0001-5570-8290

\begin{abstract}
The article presents a simulation of a ship running aground. It introduces the analytical description, as well as the methodology of carrying out strength calculations when creating engineering tasks related to the topic. It shows the state of stresses and deformations of the hull of a modern minehunter after a collision with the bottom for two immersion depths. Research and development opportunities for future considerations are highlighted in the conclusions.
\end{abstract}

Key words:

Destroyer of mines, collision with the bottom, hull strength, finite element method.

Research article

(c) 2021 Radosław Kiciński, Wojciech Jurczak, Krzysztof Świątek This is an open access article licensed under the Creative Commons Attribution-NonCommercial-NoDerivatives 4.0 license (http://creativecommons.org/licenses/by-nc-nd/4.0/) 
The analysis of the strenght of the ship's hull after running aground

\section{INTRODUCTION}

By nature, ships operate in the aquatic environment. Nowadays, the bottoms of popular sea basins are quite known and are described by the so-called bathymetric maps. These maps also indicate the local shallow waters called shallows. These are gravelly or sandy places in sea basins, formed as a result of sedimentation of material carried by water with a local reduction of its flow rate [1]. However, despite the apparently known profile of the seabed, there are cases of ships running aground, as exemplified by the cruise ship Costa Concordia. On January 13, 2012, the ship hit one of the Italian islets at a depth of 8 meters, approximately 90 meters from the coast [2]. As a result of the collision, water began to seep into the ship and the vessel began to tilt gradually. The water displaced the center of gravity of the ship and as a result of the cruiser leaning against the shallow, the stability changed, which caused the ship to heel to starboard. Eventually, the unit settled to the bottom with a heel of $80^{\circ}$ (Fig. 1) [3].

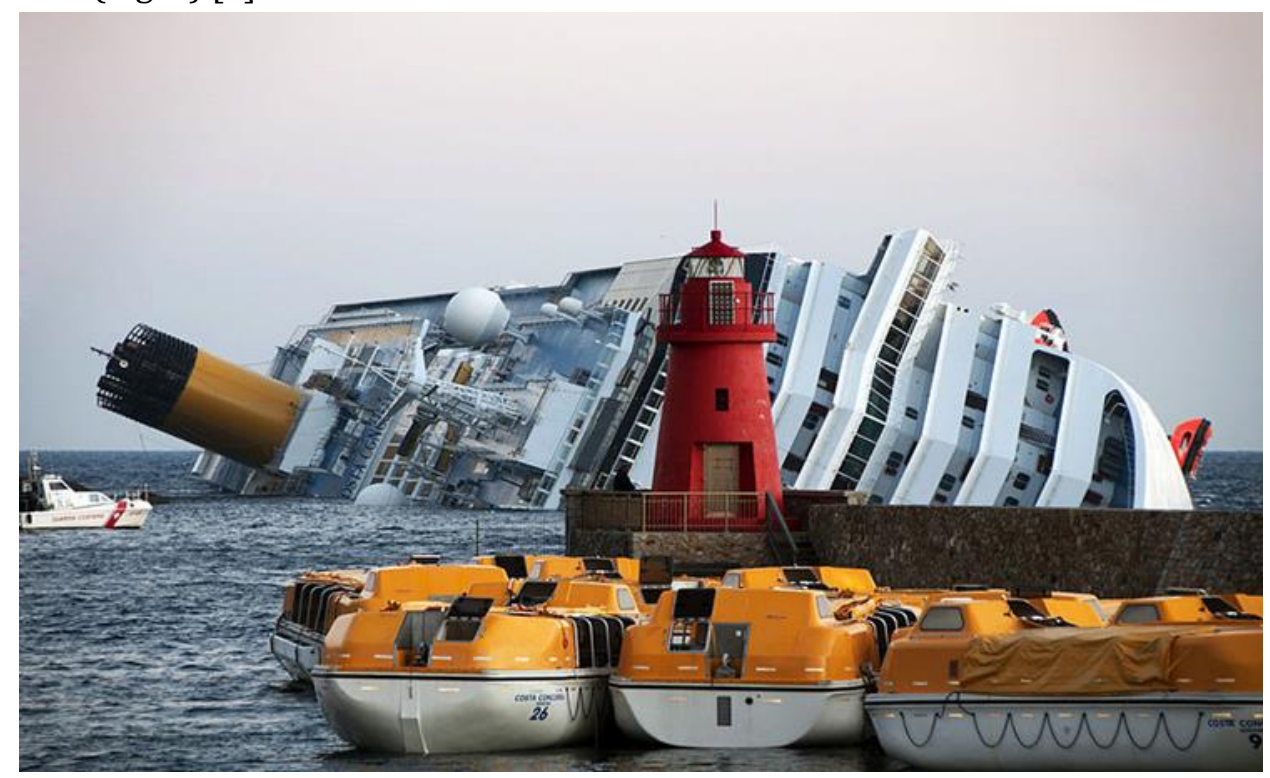

Fig. 1. The cruise ship Costa Concordia after running aground (source: https://commons.wikimedia.org/wiki/File:Collision_of_Costa_Concordia_27.jpg)

The Polish Navy also operates in an area prone to shallowing. In particular, in the area of the Puck Bay, where there are spits and geological formations such as the Hel Peninsula, Cypel Rewski or Ryf Fok. However, this is not an area of operational interest for submarines or combat ships. However, during World War II this 
region was well-known for the functioning of a torpedo platform. It was a German torpedo-assembly facility and torpedo test firing facility in the bay area. The building consisted of an assembly hall, engineering and technical rooms, as well as an observation tower used to track the path of the launched torpedo. At the bottom of the bay there was a hollow corridor through which the torpedo was moving. Next, the torpedoes were fished out and analyzed in the facility [4]. Thus, there is a significant risk that some of the tested torpedoes could not be found, which makes the Puck Bay a potential operational area for mine-destroyers or minesweepers (Fig. 2).

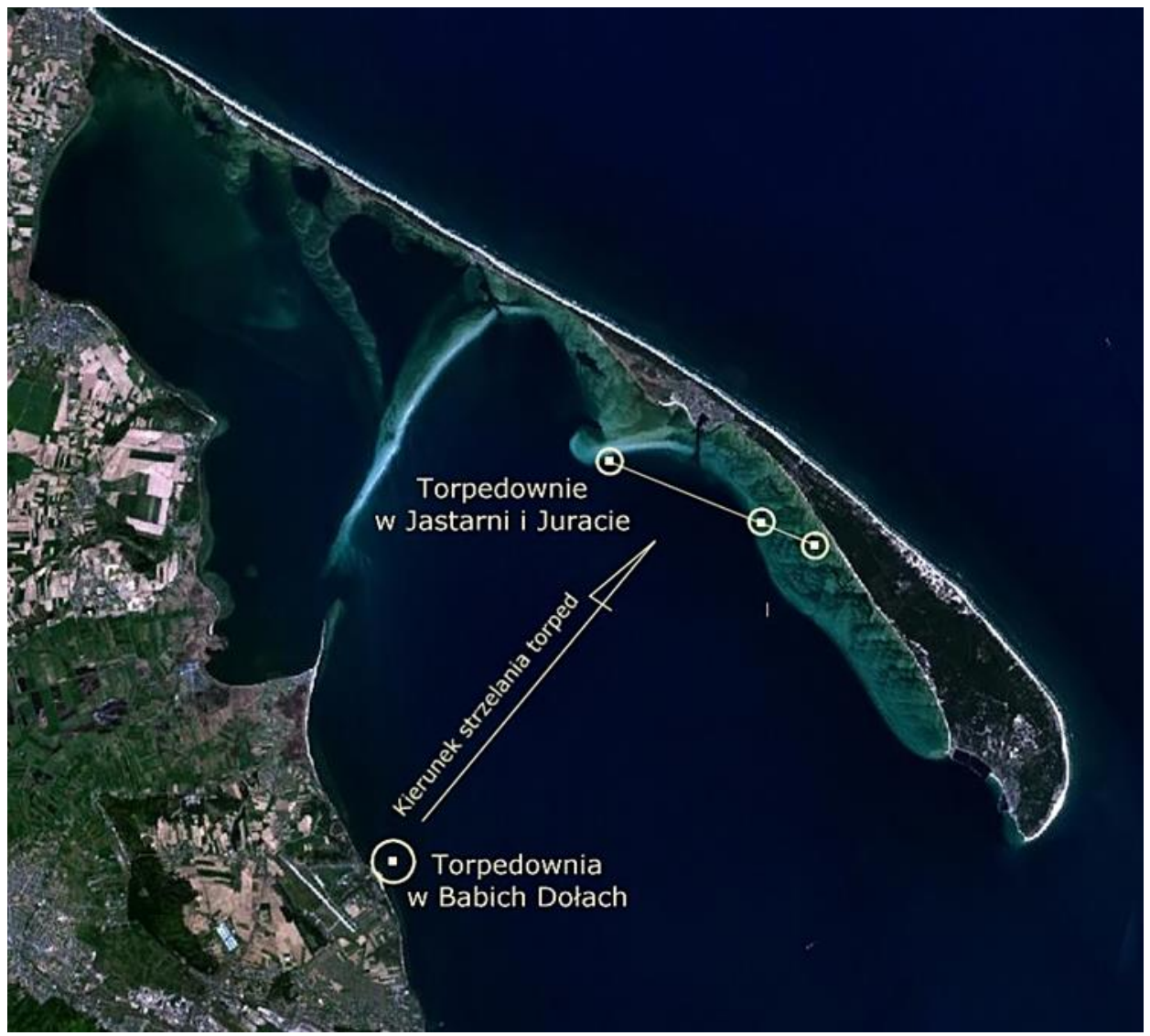

Fig. 2. Torpedo platforms in Gdynia and along the Hel Peninsula (http://augustyna.pl/09/0118/index.php?what=8)

In connection with the modernization of the Polish Navy's fleet, the minehunter Kormoran II may be assigned to such activities, which makes it endangered by running aground in the mentioned area. It is worth considering whether the hull made of austenitic steel 1.3964 will be resistant to a collision with local shallow water. 
The analysis of the strenght of the ship's hull after running aground

\section{THE SHIP'S RUNNING AGROUND}

When a ship runs aground, a number of unforeseen situations can arise. Let us limit ourselves to situations where the ship runs aground bow or amidships. When the ship runs aground amidships, and if there is no trim or heel, the stability is calculated as during docking. However, the magnitude of the reaction force is calculated on the basis of the volume of the emerged part of the hull on the basis of the displacement curve or using the formula [5]:

$$
R=\gamma \Delta T A_{w}
$$

where:

$R$ - reaction force, $\mathrm{N}$

$\gamma=\rho g-$ specific gravity of water, $\mathrm{N} / \mathrm{m}^{3}$

$\Delta T$ - draft change, $\mathrm{m}$

$A_{w}$ - hull cross-sectional area on the waterline, $\mathrm{m}^{2}$

If a ship has run aground bow or stern, resulting in a trim, stability calculations are more complicated. Analytically, such a task is solved as if a load had been unloaded from the ship. The magnitude of the weight is compared to the bottom reaction force, and the place of the weight determines where the reaction force is applied. Fig. 3 shows the ship aground, leaning forward. Until the grounding, the ship had a blue dotted waterline, while after running aground, the waterline changed to a solid blue line. At the place of the draft marks, the draft $\left(T_{r}\right)$ and bow $\left(T_{d z}\right)$ are marked. The bottom reaction force is represented by the force $\mathrm{R}$ acting on the arm a against the center of gravity of the $\operatorname{ship} G$. The figure also shows the force of the gravity of the ship, which is equal to the buoyancy force $D$, and the metacentre $M$. Knowing the metacentre coordinates is necessary to determine the axis of rotation of the ship as well as to find forces of the bottom reaction to the ship's shell. These data are available in the detailed ship documentation and have not been presented in this study. Knowing the coordinates of the center of gravity and the metacentre, the value of $H$ can be determined, which is the longitudinal metacentric height. A more detailed description of determining the ship's emergency stability can be found in [5], [6].

$1(224) 2022$ 


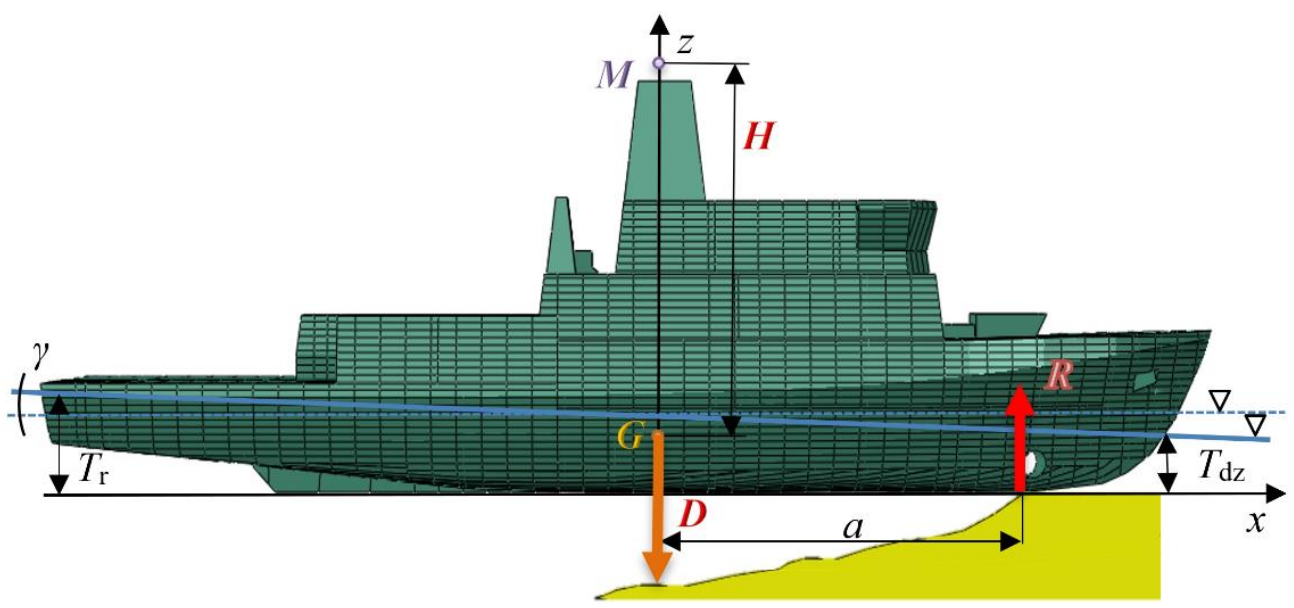

Fig. 3. A ship aground

On the basis of the quoted values, the magnitude of the reaction force is calculated from the fomula:

because

$$
\operatorname{tg} \gamma=\frac{R \cdot a}{D \cdot H}
$$

$$
\operatorname{tg} \gamma=\frac{T_{r}-T_{d z}}{L}
$$

So ultimately the reaction force is:

where:

$$
R=\frac{D \cdot H\left(T_{r}-T_{d z}\right)}{a \cdot L}
$$

$R$ - bottom reaction force, $\mathrm{N}$;

$D$ - buoyancy force, $\mathrm{N}$;

$H$ - longitudinal metacentric height, $\mathrm{m}$;

$T_{r}$ - stern draft, m;

$T_{d z}$ - bow draft, m;

$a$ - place of impact to the bottom, $\mathrm{m}$;

$L$ - length between draft measurements (between draft marks), m.

As can be seen from the above presented considerations, the analytical determination of the seabed reaction does not describe in any way the impact of such reaction on the hull. A collision of a ship with the bottom may have various consequences, therefore, at least a partial analysis of the hull structure should be carried out using the finite element method (FEM). 
The analysis of the strenght of the ship's hull after running aground

\section{PREPARATION OF THE SIMULATION}

The preparation of the simulation began with obtaining material characteristics. The material characteristics were obtained thanks to the static tensile test in accordance with the norm PN - EN ISO 6892 - 1: 2016 - 09 [7]. Due to the high strength and hardness of the tested steel, the areas for the samples were cut from its sheet (parallel and perpendicular to the rolling direction) using water jet cutting.

The steel used in the research 1.3964 is austenitic, stainless steel with the symbol: EN/DIN X2CrNiMnMoNNb 21-16-5-3 [8], [9]. Its strength as a construction material depends on the type of treatment it is subjected to at the metallurgical stage and allows for a tensile strength of $700 \div 950 \mathrm{MPa}$.

Based on the data obtained from the static tensile test, the actual material characteristics were determined in accordance with the algorithm described in [10] - [13]. In CAE programs, entering material data with the use of table (graph points) is cumbersome and causes prolongation of calculations due to extrapolation between curve points. This problem can be avoided by using material models. In fastchanging processes, such a material can be described using a simplified Johnson Cook (J - C) polynomial [14] in the form:

$$
\begin{gathered}
\sigma=\left(A+B \varepsilon^{n}\right)\left(1+C \ln \frac{\dot{\varepsilon}}{\varepsilon_{0}}\right) \\
\sigma=\left(302+1250 \varepsilon^{0,3334}\right)\left(1+0,006 \ln \frac{\dot{\varepsilon}}{0,0001}\right), \mathrm{MPa}
\end{gathered}
$$

where:

$\sigma$ - stresses in the material;

$A$ - material constant $\approx R_{e}$ - yield stress;

$B$ - hardening parameter;

$\varepsilon$ - reduced plastic deformation;

$n$ - strengthening exponent;

$C$ - material sensitivity factor to the deformation rate;

$\dot{\varepsilon}$ - reduced speed of plastic deformation;

$\dot{\varepsilon}_{0}$ - velocity of quasi-static deformation.

In order to determine the material model, the MATLAB environment was used, in which the written program using the so-called engineering method [15] fits the curve by regression to the compiled data with an accuracy of more than $95 \%$. The material characteristics developed in this way are shown in Fig. 4. 


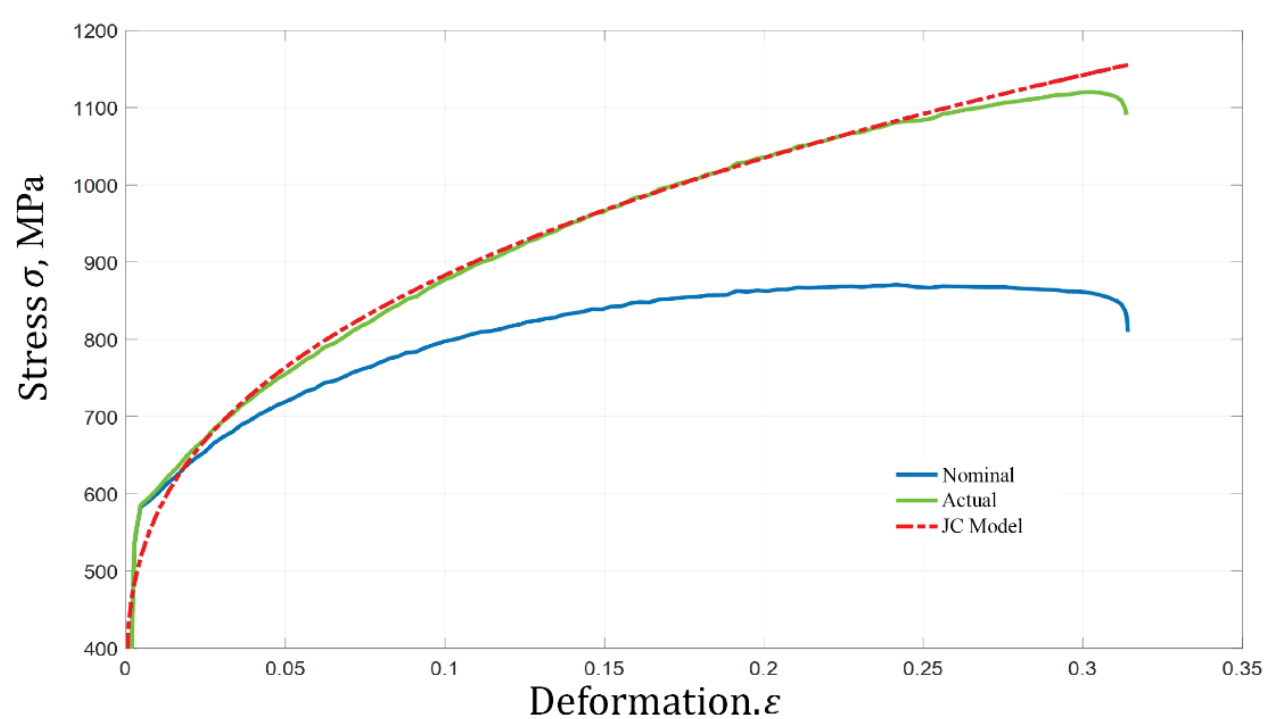

Fig. 4. Comparison of the results of a static tensile test and the proposed J - C model generated by the program.

Next, on the basis of photos and promotional materials [16] - [18], the approximate geometry of the ship's hull was reconstructed and the layout of rooms inside the ship was proposed. The local stiffening of the hull was modeled, and then the ship running aground for two different depths was simulated.

Each FEM task should be treated individually, using appropriate constitutive equations. In case of running aground, the constitutive equation is more complex due to additional criteria. They can be presented in the form of:

$$
M(U) \ddot{U}+C \dot{U}+K\left(U, \dot{\varepsilon}_{\mathrm{pl}}\right) U=F\left(m_{\mathrm{okreqtu}}, \alpha, v, t, C_{\mathrm{int}}, \mu, T\right)
$$

where:

$K$ - structure stiffness matrix;

$M$ - inertia matrix;

$C=\alpha M+\beta K$ - damping matrix, where $\alpha$ and $\beta$ are constant coefficients;

$U, \dot{U}, \ddot{U}$ - vector of displacement, velocity and acceleration;

$F$ - vector of loads;

$\dot{\varepsilon}_{\mathrm{pl}}$ - deformation velocity vector;

$v$ - the speed of the ship before the impact;

$\mathrm{t}$ - interaction time;

$\alpha$ - hull impact angle against the bottom;

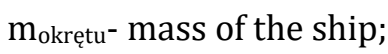

$C_{\text {int }}$ - interactions and contact forces between colliding FEM elements; 
The analysis of the strenght of the ship's hull after running aground

$\mu$ - friction between FEM elements;

$T$ - ship's draft.

Taking into account the complexity of the contact task and the constitutive equation (6), the simulations were performed only for the part of the ship's bow with stiffeners. The model was made using shell and beam elements (Fig. 5). The part of the ship not participating in the calculations was modeled as a concentrated mass with appropriate moments of inertia in relation to the designated part of the ship. Structural elements of the ship located at a large distance from the collision site do not play a significant role in the local strength of the structure, however, according to the constitutive equation, their mass constitutes a significant part of the load vector.

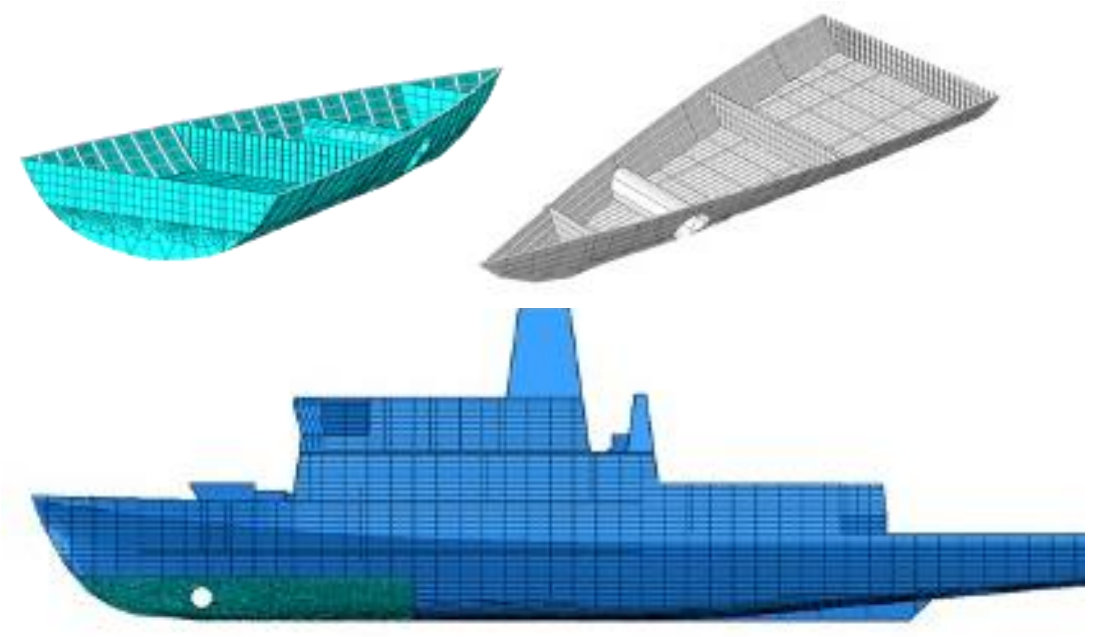

Fig. 5. Ship model used for FEM simulation

The next step was to model the interaction of the ship's hull with the bottom. For this purpose, the shape of the sandy bottom was modeled. The sand was modeled as a perfectly elastic body with the following parameters [19]:

- Young's modulus $E=20 \mathrm{MPa}$;

- Poisson number $v=0.3$;

- density $\rho=1500 \mathrm{~kg} / \mathrm{m}^{3}$;

Additionally, the friction between all FEM elements was modeled, the coefficient of which was $\mu=0.2$. 


\section{SIMULATION RESULTS}

Using the prepared geometry, a simulation of the ship grounding was carried out for two draft variants. The simulation was performed at the speed of $12 \mathrm{kt}$ $(6 \mathrm{~m} / \mathrm{s})$. The results are shown in the figures below (Fig. 6, Fig. 7).

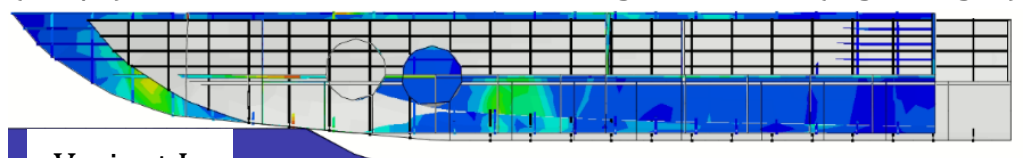

Variant I

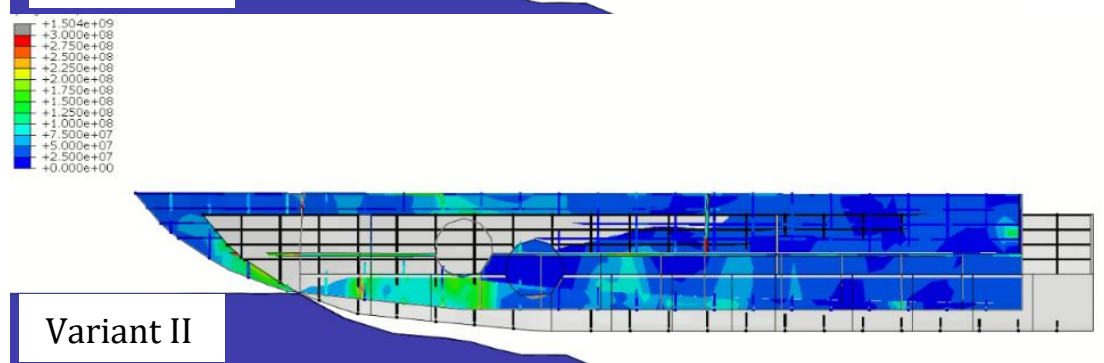

Fig. 6. Comparison of the initial and final positions of the model for two variants of immersion

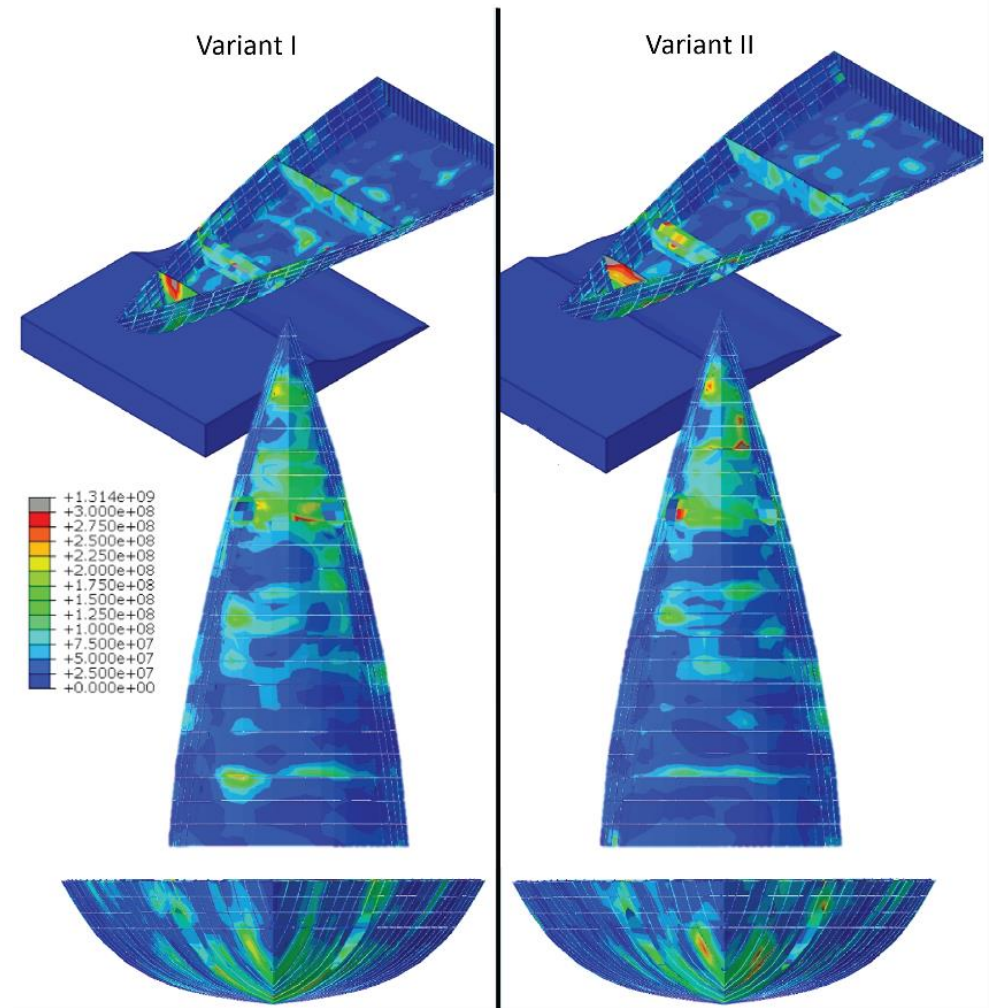

Fig. 7. FEM simulation results for two variants. Reduced stress distribution $\mathrm{HMH}(\mathrm{Pa})$ 
The analysis of the strenght of the ship's hull after running aground

On the basis of the conducted analysis, it was found that during the hitting the bottom, the stresses in the ship's hull may appear excessing the yield strength of the material $\mathrm{R}_{\mathrm{e}}=302 \mathrm{MPa}$, which will result in permanent plastic deformation. These deformations occur mainly at the point of connection of the hull's section with the concentrated mass, which is the result of the simplifications used, and at the point of contact with the bottom. The stress values do not indicate any damage to the plating, therefore it can be concluded that the hull will remain tight after the collision with the sandy bottom. Another conclusion is the fact that with the change of the impact depth, the angle of the bow hitting the bottom changes and transfers the loads to the remaining elements of the hull, causing greater deformations at the point of contact with the bottom.

\section{CONCLUSIONS}

On the basis of the conducted analysis, it was found that it is possible to perform strength calculations of the ship's hull during running aground. One need to be aware that the simulation relates only to the hull's fragment in a given specific case and a given speed. Moreover, during a collision of a ship with the bottom, its stability changes, which affects the buoyancy force and righting moments, causing the ship to heel to one side. The performed simulation shows only the moment of the vessel's collision with the bottom without any stability considerations. Conducting a simulation of the entire unit grounding, taking into account the deformation of the hull, the change of the buoyancy and immersion force, requires greater computing power and a more complex mathematical apparatus.

\section{REFERENCES}

[1] Stanisław Pietkiewicz i Stefan Żmuda, Słownik pojęć geograficznych. Warszawa: Wiedza Powszechna, 1973.

[2] M. Imarisio, „Ammutinati in difesa dei passeggeri”, Corriere della Sera. http://www.corriere.it/cronache/12_gennaio_17/ammutinati-passeggeri_fdf69cf2-40d0-11e1-b71c2a80ccba9858.shtml (access: 09-0ct-2020).

[3] „Le telefonate della Capitaneria a Schettino «Comandante che fa, vuole tornare a casa?»",Corriere della Sera. http://www.corriere.it/cronache/12_gennaio_16/procuratore-grosseto-schettino-fermato-perche-poteva-fuggire_76f76cec-4029-11e1-a5d275a8a88b1277.shtml (access: 09-Oct-2020).

[4] A. Komorowski, Obiekty podwodne i militaria Zatoki Gdańskiej: praca zbiorowa. Impuls Plus Consulting, 2001.

[5] Teoria okrętów podwodnych [Submarine Theory - in Polish]. Gdynia: Polish DoD, 1965. 
[6] Charchalis Adam, Opory okrętów wojennych i pędniki okrętowe (Resistance force of warships and ship propellers - in Polish). Gdynia: Akademia Marynarki Wojennej im. Bohaterów Westerplatte, 2001.

[7] „Polish Norm PN-EN ISO 6892-1:2016, Metallic materials. Tensile testing. Part 1 Method of test at room temperature". Polish Committee for Standardization, 2016.

[8] Lincoln Electric, „Katalog materiałów spawalniczych Lincoln Electric [Lincoln Electric welding consumables catalog - available in Polish]".

[9] Metalcor GmbH , Essen, Germany, „Metalcor 1.3964, Alloy 50 - Product Catalog”.

[10] B. Szturomski, Inżynierskie zastosowanie MES w problemach mechaniki ciała stałego na przykładzie programu ABAQUS [Engineering application of FEM in problems of solid mechanics on the example of the ABAQUS program - available in Polish]. Gdynia: Wydawnictwo Akademickie AMW, 2013.

[11] Szturomski B., „Charakterystyka dynamiczna stali podwyższonej jakości w modelu Johnsona-Cooka na potrzeby symulacji procesów szybkozmiennych w programach CAE [Dynamic characteristics of high-quality steel in the Johnson-Cook model for the needs of fast-changing processes CAE simulations-in Polish]", Logistyka, t. 4, 2014.

[12] L. Z. Kong, J. Shuai, X. Y. Zhou, K. Huang, i G. J. Yu, „True stress-logarithmic strain curves test of pipeline steels using 3D digital image correlation", OPTOELECTRONICS AND ADVANCED MATERIALS - RAPID COMMUNICATIONS, t. Vol 9., nr 11-12, 2015.

[13] W. Jurczak, Z. Zatorski, B. Szturomski, K. Świątek, L. Flis, i J. Zdunek, „Wyznaczanie rzeczywistych, dynamicznych charakterystyk wytrzymałościowych stali austenitycznej oraz stopów aluminium - sprawozdanie z pracy badawczej statutowej pk. Austenka [Determination of true and dynamic strength characteristics of austenitic steel and aluminum alloys - report on statutory research under the Austenka code - available in Polish]". Akademia Marynarki Wojennej, 2019.

[14] G. R. Johnson i W. H. Cook, „A constitutive model and data for metals subjected to large strains, high strain rates", Proceedings of the 7th International Symposium on Ballistics, 2009.

[15] Leszek Flis, „Identyfikacja parametrów równania konstytutywnego Johnsona-Cook'a w odniesieniu do symulacji MES [Identification of parameters of the Johnson-Cook constitutive equation for FEM simulation - in Polish]", XIII Konferencji n.t. Techniki Komputerowe w Inżynierii 2014, 2014.

[16] „Kolejne etapy budowy okrętów typu «KORMORAN II» [Next stages of construction of «KORMORAN II» ships - available in Polish]", Remontowa Shipbuilding. http://www.remontowa-rsb.pl/aktualnosci/kolejne-etapy-budowy-okretow-typukormoran-ii/ (access: 02-Apr-2020).

[17] „The «Kormoran II» minehunter among the highest export potential products of the Polish defense industry", Ośrodek Badawczo-Rozwojowy Centrum Techniki Morskiej S.A., wrz. 03, 2019. https://ctm.gdynia.pl/en/the-kormoran-ii-minehunter-among-the-highest-export-potential-products-of-the-polish-defense-industry/ (access: 29-Jun-2020).

[18] B. Szturomski, A. Grządziela, i R. Kiciński, „Analysis of the state of stress in the hull of the ship Kormoran II loaded with non - contact mine explosion”, Solid State Phenomena, t. 236, s. 3-13, 2015. 
The analysis of the strenght of the ship's hull after running aground

[19] „Foundation Analysis and Design 5th Edition Joseph E. Bowles”, Scribd. https://www.scribd.com/doc/139025162/Foundation-Analysis-and-Design-5th-Edition-Joseph-E-Bowles (access: 16-Oct-2020). 